\title{
Pengembangan Hypothetical Learning Trajectory Berbasis Realis- tics Mathematics Education Geometri Transformasi pada Topik Rotasi
}

\author{
Rafki Nasuha Ismail 1, Ahmad Fauzan ${ }^{2}$, Made Arnawa ${ }^{3}$, Armiati $^{4}$ \\ 1,2,4 Universitas Negeri Padang (UNP), Padang, Indonesia \\ ${ }^{3}$ Universitas Andalas (Unand), Padang, Indonesia \\ ${ }^{*}$ Corresponding Author
}

\begin{tabular}{l} 
Informasi Artikel \\
\hline DiterimaRedaksi: 02 Februari 2021 \\
RevisiAkhir: 18 Maret 2021 \\
DiterbitkanOnline: 30 Juni 2021 \\
Kata Kunci \\
\hline Hypothectial Learning Trajectory \\
Realisticcs Mathematics Education \\
Transformasi Geometri \\
Korespondensi \\
\hline E-mail: \\
rafki.nasuhaismail25@gmail.com
\end{tabular}

\section{A B S T R A C T}

The purpose of this research is to produce a Hypothetical Learning Trajectory for geometric transformation material on the topic of rotation using the context of batik motifs and the Ferris wheel game. The research method used is design research. The learning approach used is Realistic Mathematics Education Indonesia (RME). Hypothetical Learning Trajectory (HLT) was developed from learning activities using the context of batik motifs and the Ferris wheel game. The research subjects were three students of class IX SMPN 7 Bukittinggi. Theoretical development was carried out through designing learning activities with HLT design at the preliminary stage, carrying out one to one activities in teaching experiments and retrospective analysis. Data was collected by observation, interviews, and documentation. After the observations were made, the results of the LKPD work were collected which were given to students, interviewed students. The results obtained from the interview process, students can use the HLT design that was developed because it has a systematic guide sequence to teach the topic of geometric transformation about rotation in the one to one implementation. what is predicted and what is anticipated. So the results of the HLT design for geometric transformation materials on the topic of rotation using the context of batik motifs and the Ferris wheel game are obtained.

Tujuan penelitian menghasilkan Hypothetical Learning Trajectory materi transformasi geome tri pada topik rotasi menggunakan konteks motif batik dan permainan bianglala. Metode penelitian yang digunakan adalah design research Pendekatan pembelajaran yang digunakan adalah Realisticcs Mathematics Education Indonesia (RME). Hypothetical Learning Trajectory (HLT) dikembangkan dari aktivitas pembelajaran menggunakan konteks motif batik dan permainan bianglala. Subjek penelitian adalah tiga peserta didik kelas IX SMPN 7 Bukittinggi, Pengembangan secara teoritis dilaksanakan melalui perancangan aktivitas pembelajaran dengan desain HLT pada tahap preliminary, melaksanakan kegiatan one to one pada teaching experiment dan restrospective analysis. Pengumpulan data dilakukan dengan observasi, wawancara, dan dokumentasi. Setelah observasi dilakukan maka dikumpulkan hasil pengerjaan LKPD yang diberikan pada peserta didik, mewawancarai peserta didik. Hasil penelitian diperoleh proses wawancara, peserta didik dapat menggunakan desain HLT yang dikembangkan karena memiliki urutan panduan yang sistematis untuk mengajarkan topik transformasi geometri tentang Rotasi pada pelaksanaan one to one menunjukkan bahwa penggunaan konteks motif batik dan permainan bianglala pada desain HLT transformasi geometri tentang Rotasi sesuai antara apa yang diprediksi dan antipasi yang dilakukan. Jadi diperoleh hasil rancangan HLT materi transformasi geometri pada topik rotasi menggunakan konteks motif batik dan permainan bianglala.

\section{Pendahuluan}

Hypothetical Learning Trajectory (HLT) sebuah lintasan belajar dengan harapan apa yang mungkin terjadi, baik proses berpikir peserta didik yang akan belajar maupun hal-hal yang akan terjadi dalam proses pembelajaran. HLT terdiri dari tujuan pembelajaran, kegiatan pembelajaran dan proses pembelajaran hipotetis - prediksi dan prediksi bagaimana pemikiran dan pemahaman peserta didik akan berkembang dalam konteks kegiatan pembelajaran (Faik Camci, Dilek Tanışl, 2020; Fauzan \& F Diana, 2020; Towe \& H Julie, 2020; Fuadiah, ZA Sawitri, 2020; Alim et al., 2020; Rooselyna Ekawati, et al. 2020. Lebih lanjut guru dapat menggunakan HLT untuk merancang proses pembelajaran yang meningkatkan hasil belajar peserta didik (Rongjin Huang, et al., 2018 ). Hypothetical learning trajectory akan membantu guru menerapkan pendekatan RME (Fauzan dan Diana, 2020; Towe and Julie, 2020; Alim, N Hermita, dkk, 2020; Taufina, Ah- 
mad Fauzan dkk, 2019; Gee, Fauzan and Atmazaki, 2018; Febrian, Puji Astuti, 2018; Burçin Gökkurt Özdemir, 2017. Begitu juga HLT mendukung model, strategi, media (multi media interaktif) Alim, Hermita, dkk, 2020. Pengembangan bahan ajar dengan media 3D juga dapat difasilitasi HLT Amir,dkk, 2018, HLT juga membantu guru pada kemampuan matematis peserta didik Gee, Fauzan dan Atmazaki, 2018; Fikri Mukasyaf,dkk, 2019; Taufina, Ahmad Fauzan,dkk, 2019. Demikian pula penilaian yang sesuai dengan tahapan berpikir peserta didik juga menyarankan bahwa guru membutuhkan hipotesis pembelajaran untuk merancang pembelajaran yang akan konsisten dengan pola berpikir peserta didik di kelas sesuai dengan karakteristik peserta didik [29].

Beberapa penelitian lainnya mengenai HLT telah dilakukan. Ayunika (2011) menggunakan HLT untuk meningkatkan pemahaman konseptual. Kesimpulan penelitian menunjukkan bahwa dengan bantuan HLT peserta didik dapat mengembangkan pemahaman konsep matematikanya. Dikembangkan sejalan dengan proses pembelajaran di kelas, HLT membantu peserta didik memperluas pemahaman konsep mereka. [28] mencatat bahwa masalah pembelajaran matematika yang tidak terkait dengan kehidupan sehari-hari akhirnya memotivasi pendidik matematika Indonesia untuk mencari metode pembelajaran yang berpusat pada keterampilan teknis untuk mereformasi pendidikan matematika berbasis resolusi. masalah dalam kehidupan sehari-hari. Metode pembelajarannya adalah Realistic Mathematics Education (RME) dan umumnya selaras dengan budaya, geografi, dan kehidupan Indonesia [29].

Proses penemuan kembali suatu konsep matematika menurut pendekatan RME yakni peserta didik difasilitasi untuk menemukan strategi sendiri penyelesaian suatu masalah dengan memanfaatkan fenomena kontektual yang digunakan untuk menuju matematika formal. Menurut [14], proses yang demikian disebut proses matematisasi horizontal dan vertikal. Pada matematisasi horizontal, peserta didik menggunakan alat matematika non formal berupa simbol, tabel, atau grafik untuk mengorganisasi dan memecahkan masalah berdasarkan situasi kontekstual. Sedangkan, matematisasi vertikal adalah proses pengorganisasian dalam sistem matematika itu sendiri untuk menghasilkan matematika yang lebih formal. Dalam hal matematisasi horizontal dan vertikal ini peserta didik mengembangkan model sendiri (model of situation) yang berfungsi untuk menjembatani peserta didik berpikir dari situasi real (matematika non formal) ke situasi matematika yang lebih formal (matematika formal) untuk memperoleh model for mathematics [7].

Pada umumnya perkembangan kognitif anak dimulai dari yang konkret dan berangsurangsur berkembang ke arah yang abstrak. Setiap anak mungkin memiliki jalan yang berbeda dari konkret ke abstrak. Ini mungkin tidak melalui beberapa langkah untuk orang yang cepat, tetapi tidak mungkin melalui beberapa langkah untuk orang yang tidak cepat. Inovasi pembelajaran matematika yang berorientasi pada hubungan matematika dengan realitas dan kondisi budaya peserta didik, peneliti telah membuat desain pembelajaran berputar menggunakan motif batik dan permainan bianglala sebagai titik awal atau konteks pembelajaran. Konteks tersebut dipilih karena dekat dengan peserta didik dan merupakan bagian dari budaya peserta didik, sehingga mudah ditemukan dalam kehidupan sehari-hari peserta didik. Pembelajaran matematika dengan konteks erat kaitannya dengan penggunaan RME. Dua pandangan penting dari Freudenthal adalah bahwa matematika harus dekat dengan peserta didik dan relevan dengan kehidupan sehari-hari, dan bahwa matematika sebagai aktivitas manusia juga harus memberikan kesempatan kepada peserta didik untuk melakukan pembelajaran. Aktivitas pada semua topik dalam matematika (Zulkardi \& Putri, 2010; Putri, 2011) melalui HLT ini diharapkan dapat menjadi kebaruan dalam pembelajaran matematika yang dapat memudahkan siswa dalam memahami konsep rotasi serta mampu memecahkan permasalahan sehari-hari yang berkaitan dengan konsep tersebut. Berdasarkan uraian masalah di atas tujuan penelitian untuk menghasilkan Hypotethical Learning Trajectory berbasis RME pada materi transformaasi geometri tentang rotasi dengan 
menggunakan konteks membatik sebagai warisan budaya dan permainan bianglala starting point.

\section{Metode Penelitian}

Metode penelitian yang digunakan dalam penelitian ini adalah design research. Tujuannya adalah untuk meningkatkan praktik pembelajaran di kelas melalui analisis interaktif tentang apa yang terjadi di kelas dan penerapannya [14]. Design research juga diartikan sebagai suatu metode yang bertujuan mengembangkan Hypothetical Learning Trajectory (HLT) kolaborasi antara peneliti dan guru meningkatkan kualitas pembelajaran [14].Tahap-tahap yang digunakan dalam penelitian ini tahap Preliminary Design dan tahap Design Experiment

Tahap preliminary design bertujuan untuk mengembangkan rangkaian kegiatan pembelajaran dan cara menilai proses pembelajaran. Studi ini meninjau literatur tentang HLT, Realistics Mathematics Educations (RME), konsep rotasi pada materi transformasi geometri dan analisis materi rotasi dalam kurikulum matematika Indonesia. Hal ini memungkinkan siswa untuk menebak ide peserta didik. Pada tahap ini didesain Hypothetical Learning Trajectory yang akan dirumuskan menjadi tujuan pembelajaran dan perangkat pembelajaran (rencana pelaksanaan belajar dan lembar kerja peserta didik). Dalam hal ini berfungsi sebagai pedoman yang dikembangkan dalam setiap kegiatan pembelajaran, bersifat fleksibel, dan dapat dikoreksi secara eksperimental, dan sudah divalidasi oleh expert review

Tahap Design Experiment ini bertujuan untuk menyelidiki dan memprediksi strategi dan ide peserta didik dalam proses pembelajaran yang sebenarnya. Langkah-langkah yang dilakukan dalam penelitian ini adalah jenis kegiatan one-on-one yang dilaksanakan di kelas IX.1 pada Senin, 26-27 November 2020. Jumlah peserta didik ada tiga orang dengan tingkat kemampuan yang berbeda yaitu kemampuan tinggi, sedang dan rendah. Hal ini diperoleh dari informasi guru Matematika kelas IX.1 SMPN 7 Bukittinggi. Pada tahap design experiment, dilakukan eksperimen HLT pada siswa kelas IX yang berkemampuan rendah, sedang, dan tinggi. Kemudian dari retrospektif diperoleh hasil percobaan dalam tahap kegiatan one to one. Terdapat dua aktivitas sebagai starting point yang dilakukan dalam tahap design experiment dan diklasifikasikan dalam beberapa tahap yaitu aktivitas dalam tahap informal, model of, dan model for dan tahap formal.

\section{Hasil dan Pembahasan}

Hasil yang diperoleh dalam penelitian ini adalah bentuk desain HLT yang di dalamnya terdapat learning trajectory untuk pembelajaran rotasi yang menggunakan motif batik dan permainan bianglala sebagai titik awal pembelajaran atau konteksnya. Hasil pada tahap preliminary design adalah merancang HLT yang diperoleh berupa rancangan lintasan belajar. Lintasan pembelajaran yang digunakan dalam penelitian ini adalah pemahaman konsep rotasi menggunakan konteks batik, yang selanjutnya meningkatkan pemahaman tentang hubungan antara koordinat awal dan koordinat hasil rotasi yang diperoleh dari proses menggambar motif batik. Jumlah tertentu dan penerapannya untuk memecahkan masalah sehari-hari dengan membangun konteks permainan bianglala. Putaran permainan bianglala mempengaruhi posisi kursi penumpang. Peserta didik akan diminta untuk menentukan jumlah putaran permainan bianglala dari soal yang diketahui. Serangkaian kegiatan pembelajaran berdasarkan lintasan belajar dan dugaan hasil berpikir peserta didik. Hal ini bertujuan untuk membantu peserta didik memahami rotasi dan menerapkannya pada masalah yang mereka hadapi dalam kehidupan sehari-hari. Berikut draf awal HLT yang mengacu pada konten materi rotasi: 


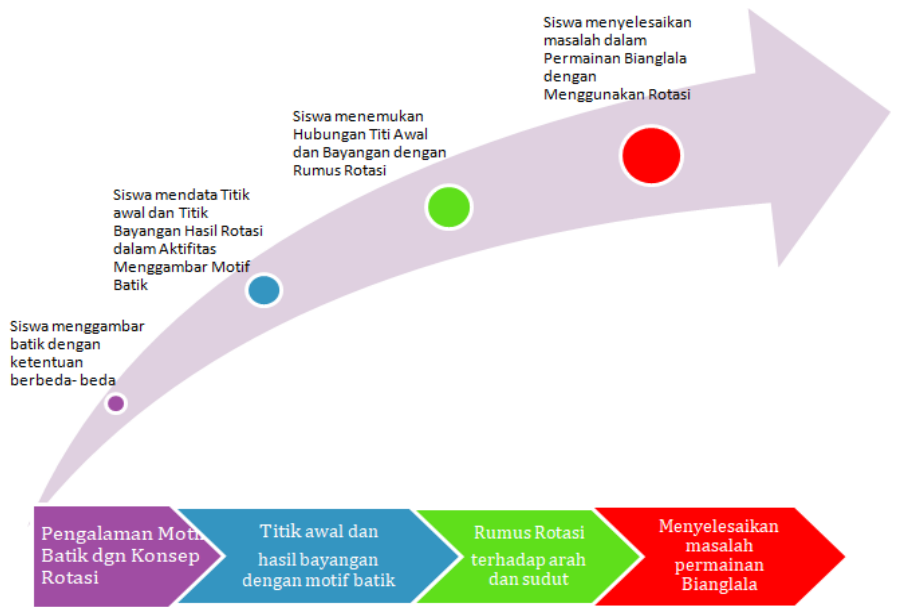

Gambar 1. Draf HLT pembelajaran rotasi

Berdasarkan rancangan HLT yang dirancang, dapat diperoleh kesimpulan pembelajaran rotasi yang ditunjukkan pada Tabel 1.

Tabel 1. Konjektur Pembelajaran Rotasi Menggunakan Motif Batik dan Permainan Bianglala

\begin{tabular}{|c|c|c|c|c|}
\hline Tahap & Aktifitas & Tujuan & Deskripsi Aktifitas & Konjektur Pemikiran Peserta didik \\
\hline Informal & $\begin{array}{c}\text { Menggambar } \\
\text { Motif Batik } \\
\text { secara bebas }\end{array}$ & $\begin{array}{l}\text { Peserta didik } \\
\text { dapat men- } \\
\text { gidentifikasi } \\
\text { masalah yang } \\
\text { berhubungan } \\
\text { dengan de- } \\
\text { formasi } \\
\text { (rotasi). }\end{array}$ & $\begin{array}{l}\text { Guru memotivasi } \\
\text { peserta didik untuk } \\
\text { mengenal gambar } \\
\text { motif pakaian sera- } \\
\text { gam batik peserta } \\
\text { didik SMP }\end{array}$ & $\begin{array}{l}\text { 1. Sudah mengenal motif batik pada dan } \\
\text { bisa menggambarkannya } \\
\text { 2. Sudah bisa memutar motif batik dengan } \\
\text { benar dan mendapatkan poin yang } \\
\text { benar } \\
\text { 3. Peserta didik belum tahu motif batik } \\
\text { dan tidak dapat menggambarkannya } \\
\text { 4. Peserta didik sudah tahu motif batik, } \\
\text { tapi belum benar dalam merotasikan } \\
\text { dari motif }\end{array}$ \\
\hline Mod & $\begin{array}{c}\text { Percobaan } \\
\text { menggambar } \\
\text { motif Batik } \\
\text { dengan Ke- } \\
\text { tentuan } \\
\text { Sudut dan } \\
\text { Arah tertentu }\end{array}$ & $\begin{array}{l}\text { Peserta } \\
\text { didik dapat } \\
\text { bereksperi- } \\
\text { men meng- } \\
\text { gambar } \\
\text { hubungan } \\
\text { antara titik } \\
\text { dan titik } \\
\text { transforma- } \\
\text { si (rotasi) }\end{array}$ & $\begin{array}{c}\text { Peserta didik } \\
\text { bekerja untuk } \\
\text { menggambar motif } \\
\text { batik yang sudah } \\
\text { ditentukan gam- } \\
\text { barnya dengan } \\
\text { arah dan sudut } \\
\text { putarnya }\end{array}$ & $\begin{array}{l}\text { 1. Karena bentuk dan ukuran bayangan } \\
\text { sama dengan bentuk aslinya, ada balasan } \\
\text { bahwa bentuk dan ukuran bayangan tid- } \\
\text { ak berubah dalam bentuk aslinya bahkan } \\
\text { setelah diputar. } \\
\text { 2. Peserta didik menjawab terjadi peru- } \\
\text { bahan posisi terhadap bangun yang } \\
\text { dirotasikan karena posisi bayangan su- } \\
\text { dah berpindah-pindah sesuai dengan } \\
\text { sudut putarannya }\end{array}$ \\
\hline $\begin{array}{l}\text { Model } \\
\text { For }\end{array}$ & $\begin{array}{l}\text { Catat titik } \\
\text { awal dan ba- } \\
\text { yangan saat } \\
\text { menggambar } \\
\text { motif batik }\end{array}$ & $\begin{array}{c}\text { Peserta didik } \\
\text { dapat } \\
\text { Menyajikan } \\
\text { hasil rotasi } \\
\text { pembelajaran } \\
\text { tentang } \\
\text { transformasi } \\
\text { (rotasi) }\end{array}$ & $\begin{array}{l}\text { Peserta didik dapat } \\
\text { mencatat titik-titik } \\
\text { dari awal dan men- } \\
\text { catat hasilnya } \\
\text { setelah memutar } \\
\text { titik-titik bayangan. } \\
\text { Guru memotivasi } \\
\text { peserta didik untuk } \\
\text { menunjukkan gam- } \\
\text { bar dari hasil } \\
\text { rotasinya }\end{array}$ & $\begin{array}{l}\text { 1. Sudah dapat menemukan hubungan an- } \\
\text { tara titik awal rotasi motif batik dan ti- } \\
\text { tik bayangan, dan Anda dapat memben- } \\
\text { tuk rumus rotasi. } \\
\text { 2. Peserta didik mengetahui adanya pola } \\
\text { atau hubungan antara koordinat benda } \\
\text { yang diputar dengan koordinat bayan- } \\
\text { gan. } \\
\text { 3. Peserta didik tidak mampu mencatat ti- } \\
\text { tik awal dan titik bayangan perputaran } \\
\text { motif batik }\end{array}$ \\
\hline
\end{tabular}




\begin{tabular}{|c|c|c|c|c|}
\hline Formal & $\begin{array}{c}\text { Temukan } \\
\text { rumus rotasi } \\
\text { saat meng- } \\
\text { gambar motif } \\
\text { batik }\end{array}$ & $\begin{array}{c}\text { Peserta didik } \\
\text { menentukan } \\
\text { rumus rotasi } \\
\text { suatu titik } \\
\text { dan men- } \\
\text { erapkan da- } \\
\text { lam } \\
\text { me- } \\
\text { nyelesaikan } \\
\text { masalah } \\
\text { yang berkai- } \\
\text { tan dengan } \\
\text { transformasi }\end{array}$ & $\begin{array}{c}\text { Guru memotivasi } \\
\text { peserta didik untuk } \\
\text { menemukan gambar } \\
\text { motif batik melalui } \\
\text { rotasi suatu titik } \\
\text { dengan arah dan } \\
\text { sudut yang diten- } \\
\text { tukan } \\
\text { Peserta didik } \\
\text { memukan rumus } \\
\text { rotasi suatu titik } \\
\text { dengan arah dan } \\
\text { sudut pusat rotasi } \\
\text { Peserta didik men- } \\
\text { erapkan rmus rotasi } \\
\text { dalam penyelesaian } \\
\text { masalah permainan } \\
\text { bianglala }\end{array}$ & $\begin{array}{l}\text { 1. Peserta didik menemukan rumus, jika } \\
\text { sebuah titik } \mathrm{A}(\mathrm{x}, \mathrm{y}) \text { dirotasikan dengan } \\
\text { sudut rotasi } 90^{\circ} \text { berlawan arah jarum } \\
\text { jam dan pusat rotasi } \mathrm{O}(0,0) \text { maka } \\
\text { koordinat bayangan adalah } \mathrm{A}^{\prime}\left(-\boldsymbol{y}_{\boldsymbol{}} \boldsymbol{x}\right) \\
\text { dan jika rotasi } 180^{\circ} \text { dan pusat } \mathrm{O}(0,0) \\
\text { maka koordinat bayangan adalah } \\
\mathrm{A}^{\prime}\left(-\boldsymbol{x}_{v}-y\right) \text {, dan jika rotasi } 270^{\circ} \text { dan } \\
\text { pusat } \mathrm{O}(0,0) \text { maka koordinat bayangan } \\
\text { adalah } \mathrm{A}^{\prime}\left(\boldsymbol{y}_{v}-\boldsymbol{x}\right) \\
\text { 2. Peserta didik tidak dapat membuat ru- } \\
\text { mus berputar karena tidak dapat } \\
\text { menemukan hubungan antara titik awal } \\
\text { motif batik dan bayangan putaran. } \\
\text { 3. Peserta didik dapat menjawab dengan } \\
\text { benar posisi awal Alya berada di nomor } \\
\text { 16, maka posisi setelah diputar } 90^{\circ} \\
\text { searah jarum jam adalah di posisi } 11 \\
\text { 4. Peserta didik tidak dapat menjawab } \\
\text { dengan benar posisi awal Alya }\end{array}$ \\
\hline
\end{tabular}

Hubungan antara jalur pembelajaran, aktivitas, dan hasil belajar yang dirancang oleh HLT adalah jalur umum bagi peserta didik yang belajar dengan menggunakan motif batik dan permainan bianglala yang digambarkan dalam bentuk gunung es pada Gambar 3 .

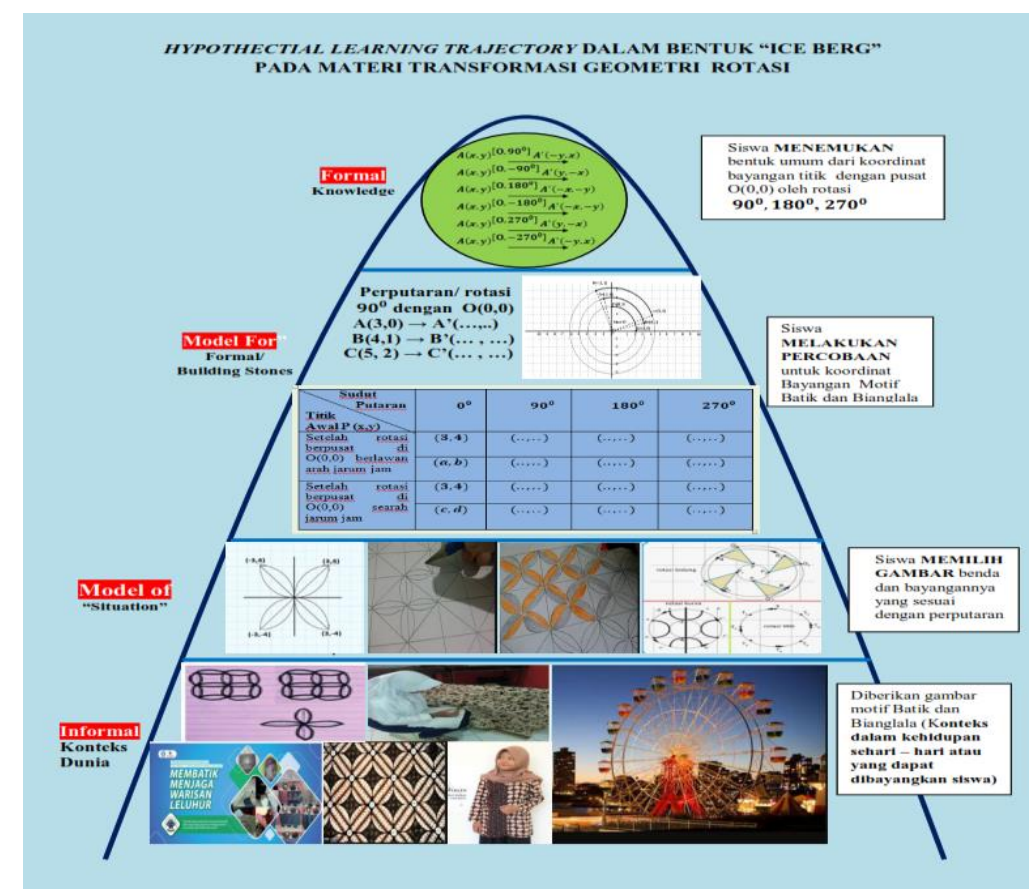

Gambar 2. Iceberg HLT dalam Pembelajaran Rotasi

Hasil pada Tahap Design Experiment dan Analysis Restrospective adalah melakukan percobaan dengan kegiatan one to one. Pada titik ini, peneliti merancang lintasan pembelajaran eksperimental pada tahap preliminary peserta didik kelas tiga SMP IX dengan kemampuan berbeda. Selanjutnya, peneliti melakukan analisis retrospektif terhadap hasil 
kegiatan one to one yang diperoleh dalam tahap design experiment. Ketiga peserta didik yang dipilih untuk mengikuti kegiatan one to one seperti pada Gambar 4:
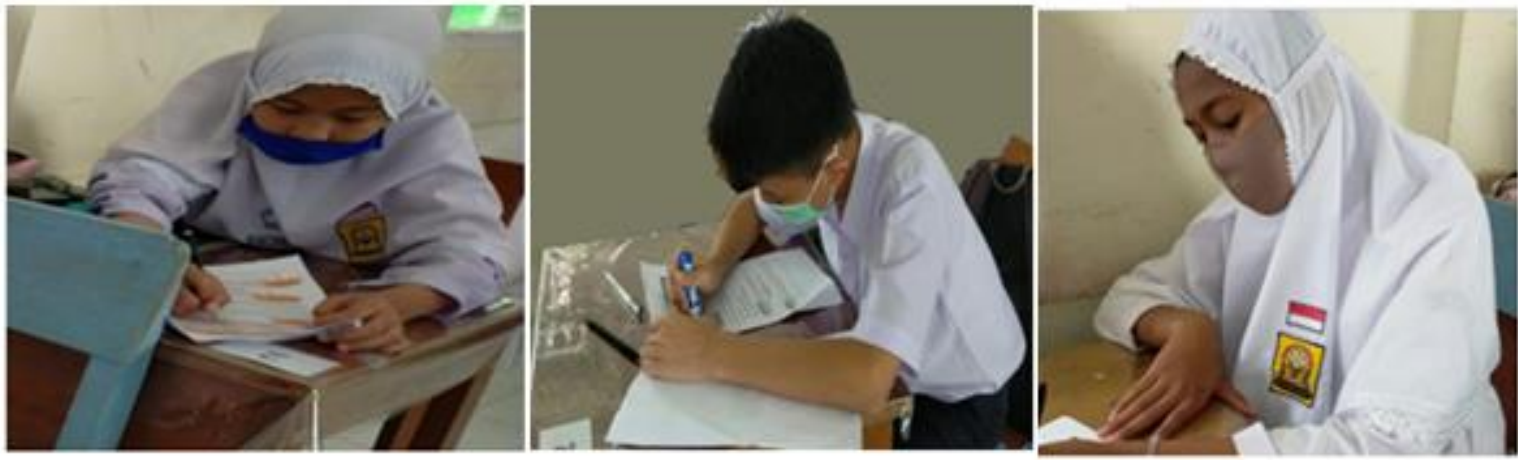

Gambar 3. Kegiatan One to One Evaluation

Beberapa hal yang dilakukan dalam kegiatan One to One Evaluation di antaranya (a) Ketiga peserta didik diminta untuk duduk di bangku masing-masing. (b) Peserta didik diberitahukan hal apa saja yang akan dilakukan, yaitu dimulai dengan membaca LKPD, memahaminya, dan mengerjakan LKPD lansgung. (c) Peserta didik diminta untuk bertanya, jika ada pernyataan yang belum dipahami. (d) Setelah LKPD dikumpulkan dan diperiksa, peserta didik diwawancarai berdasarkan jawaban yang diisi pada LKPD tersebut. Hasil dari one to one, digunakan oleh penulis untuk memperbaiki LKPD sesuai dengan hasil analisis dan hasil wawancara pada peserta didik.

Aktifitas 1. Membatik Menjaga Warisan Leluhur dengan Transformasi Geometri

Tujuan Formal: Menentukan model matematis hubungan antara suatu titik awal dengan titik hasil rotasi

\section{Konteks 1 \\ Perhatikan seragam SMP peserta didik perempuan dengan motif batik (Situasi dalam kehidupan sehari - hari atau yang dapat dibayangkan pe- serta didik Alya ingin membatik seperti Gambar 5}

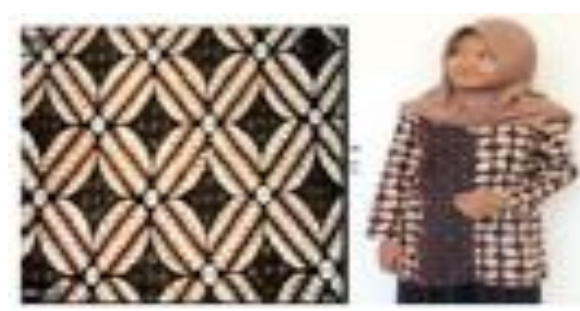

Gambar 4. Motif Batik

Agar lukisan gambar batik yang dibuat Alya terisi penuh, dia mencoba menggambarkan dengan membuat lonjong seperti elips, namun dia ragu sehingga mengajukan beberapa pertanyaan. Susunlah beberapa pertanyaan terkait masalah Alya pada gambar di atas! Akankah bentuk dan ukuran bayangan berubah ke bentuk aslinya setelah rotasi? Apakah posisi sosok yang diputar berubah? Peserta didik diharapkan dapat menjawab tentang persoalan tersebut. Berdasarkan LKPD yang dikerjakan peserta didik, hasil penelitian diuraikan sesuai kemampuannya masing-masing yang dimulai dari kemampuan rendah sebagai berikut:

\section{Peserta Didik Berkemampuan Rendah}

Berdasarkan jawaban yang dibuat dalam LKPD pada Gambar 6 


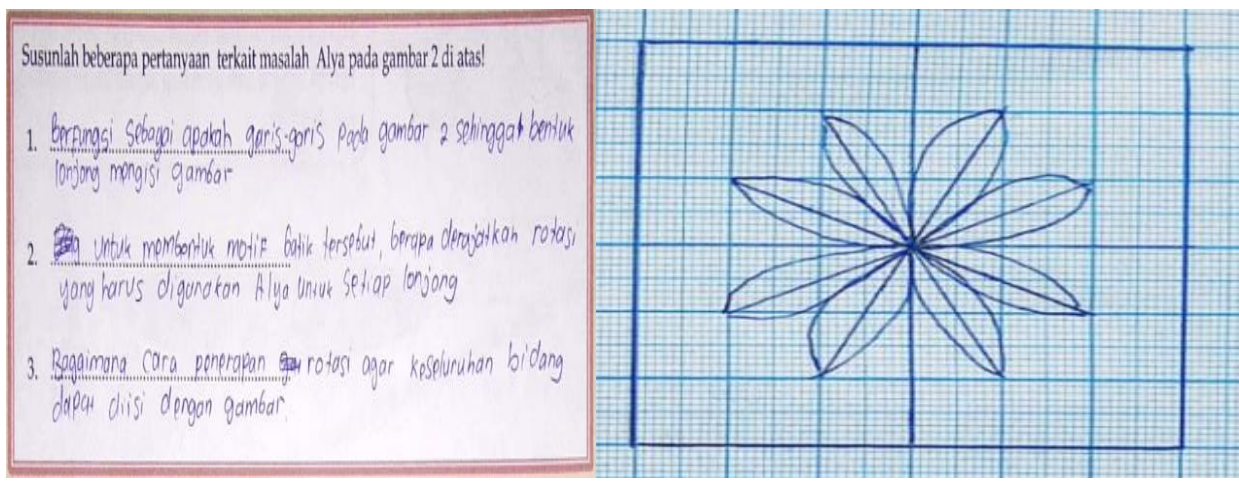

Gambar 5. Hasil Reaksi Peserta didik Kurang Mampu

Peserta didik dengan kemampuan rendah sudah mengenal batik dan motif yang ditampilkan, tapi belum mengetahui hubungan motif batik dengan rotasi, Karena mereka menduga untuk membuat bentuk oval motif dengan menggeser sehingga dugaan mereka dapat disusun berisisan dengan menggeser. Namun peserta didik yakin dengan rotasi gambar motif batik dapat diteruskan. Selanjutnya dengan adanya percobaan yang dibuat pada Tabel yang ada di LKPD membuat peserta didik terinspirasi sehingga mereka mengenal dan mengetahui cara membuat bulatan oval seperti ellip. Berikut hasil kerja peserta didik dalam LKPD yang dikerjakan. Berdasarkan LKPD yang telah dikerjakan oleh peserta didik kemampuan rendah tersebut belum mampu menyelesaikan masalah kontekstual yang diberikan. Pada jawaban peserta didik tersebut hanya menggambar kembali gambar bunga yang tertera pada soal dan menggabungkan semua bentuk ellip yang dibuat seperti rangkaian bunga. Hal ini berarti peserta didik masih belum mampu memanfaatkan prinsip rotasi. Apakah ada pola atau hubungan antara koordinat objek dengan koordinat bayangan, Jika sebuah titik A(a, b) dirotasikan dengan sudut rotasi $90^{\circ}$, $180^{\circ}, 270^{\circ}$ searah jarum jam dan pusat rotasi $\mathrm{O}(0,0)$ bagaimana koordinat bayangan dan apa hasilnya

Peserta didik dapat menjawab tentang persoalan tersebut. Berdasarkan LKPD yang dikerjakan peserta didik, sesuai kemampuannya adalah sebagai berikut: Peserta didik berkemampuan rendah. Berdasarkan jawaban yang dibuat dalam LKPD pada Gambar 7:

\begin{tabular}{|c|c|c|c|c|c|c|c|c|c|}
\hline $\begin{array}{l}\text { Sudut } \\
\text { Putaran } \\
\text { Titik } \\
\text { Awal P }(x, y)\end{array}$ & $0^{0}$ & $90^{\circ}$ & $180^{\circ}$ & $270^{\circ}$ & $\begin{array}{l}\text { Sudut } \\
\text { Putaran } \\
\text { Titik } \\
\text { Awal P }(x, y)\end{array}$ & $0^{\circ}$ & $90^{\circ}$ & $180^{\circ}$ & $270^{\circ}$ \\
\hline $\begin{array}{l}\text { Setelah rotasi } \\
\text { berpusat di } \\
O(0,0) \text { berlawan } \\
\text { arah jarum jam }\end{array}$ & $(3,4)$ & $\left(\frac{6}{4} 3\right)$ & $(-3,3,5)$ & $(-4,3)$ & $\begin{array}{l}\text { Setelah rotasi } \\
\text { berpusat di } \\
O(0,0) \text { berlawan } \\
\text { arah jarum jam }\end{array}$ & $(a, b)$ & $(+b, a)$ & $(-1,-6)$ & $(-b, 9)$ \\
\hline 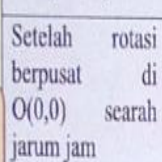 & $(3,4)$ & $(4,-3)$ & $(-3,-5)$ & $(4,3)$ & \begin{tabular}{|lr} 
Sctelah rotasi \\
berpusat ri \\
$O(0,0)$ searah \\
jarum jam
\end{tabular} & $(c, d)$ & $(d, ; i)$ & $(: l, l)$ & $(A, \theta)$ \\
\hline
\end{tabular}

Gambar 6. Jawaban Peserta Didik Kemampuan Rendah.

Pada kegiatan di atas, peserta didik mulai memahami bahwa ada persamaan antara nilai $\mathrm{x}$ dan y yang diperoleh dengan memutar titik mulai dari -titik-4, $-3,3$, 4. Kemudian melalui diskusi, peneliti menggelitik rasa ingin tahu peserta didik dan mendorong peserta didik untuk menemukan pola atau model matematika yang ada pada titik-titik rotasi yang mereka temukan. Akhir aktivitas 1 dilakukan peserta didik dengan mengarahkan untuk menjawab masalah yang dikemukakan pada aktivitas satu dengan disimpulkan bahwa model matematika yang diperoleh 
saat menggambar motif batik seragam sekolah Alya adalah rumus rotasi titik ke titik $\mathrm{O}(0,0)$ dengan besar sudut putaran $90^{\circ}, 180^{\circ}$ dan $270^{\circ}$.

Peserta didik kemampuan rendah masih ragu menentukan koordinat bayangan, sehingga masih terdapat kesalahan, jadi peserta didk kemampuan rendah diminta pelajari secara mandiri bagaimana menentukan model matematis hasil pemutaran dengan menggunakan jangka dan penggaris dan membuatnya pada kertas millimeter, dan guru memberikan latihan mandiri. Apa yang diprediksi berdasarkan kesulitan yang dialami peserta didik sesuai dan sudah diantipasi oleh guru.

\section{Peserta Didik Berkemampuan Sedang.}

Berdasarkan jawaban yang dibuat dalam LKPD pada Gambar 8:

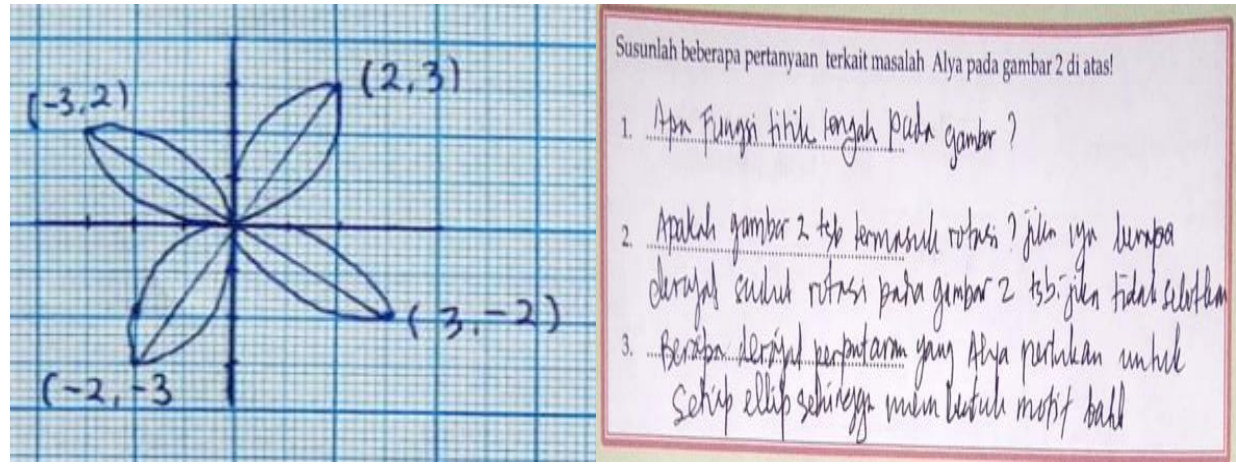

Gambar 7. Jawaban Peserta Didik Kemampuan Sedang

Peserta didik dengan kemampuan sedang sudah mengenal batik dan motif yang ditampilkan, tapi belum mengetahui hubungan motif batik dengan rotasi, Karena mereka menduga untuk membuat bentuk oval motif dengan menggeser sehingga dugaan mereka dapat disusun berisisan dengan menggeser. Namun mereka yakin dengan rotasi gambar motif batik dapat diteruskan. Selanjutnya dengan adanya percobaan yang dibuat pada Tabel yang ada di LKPD membuat peserta didik terinspirasi sehingga mereka mengenal dan mengetahui cara membuat bulatan oval seperti ellip. Berdasarkan LKPD yang telah dikerjakan oleh peserta didik berkemampuan sedang bisa menyelesaikan masalah kontekstual yang diberikan sudah dapat mengaitkan gambar ellip yang mereka ketahui dengan membuat titik koordinat ujung ellip dan menuliskan titik titik pada setiap kuadran. Peserta didik dapat menjawab tentang persoalan tersebut. Seperti Gambar 9:

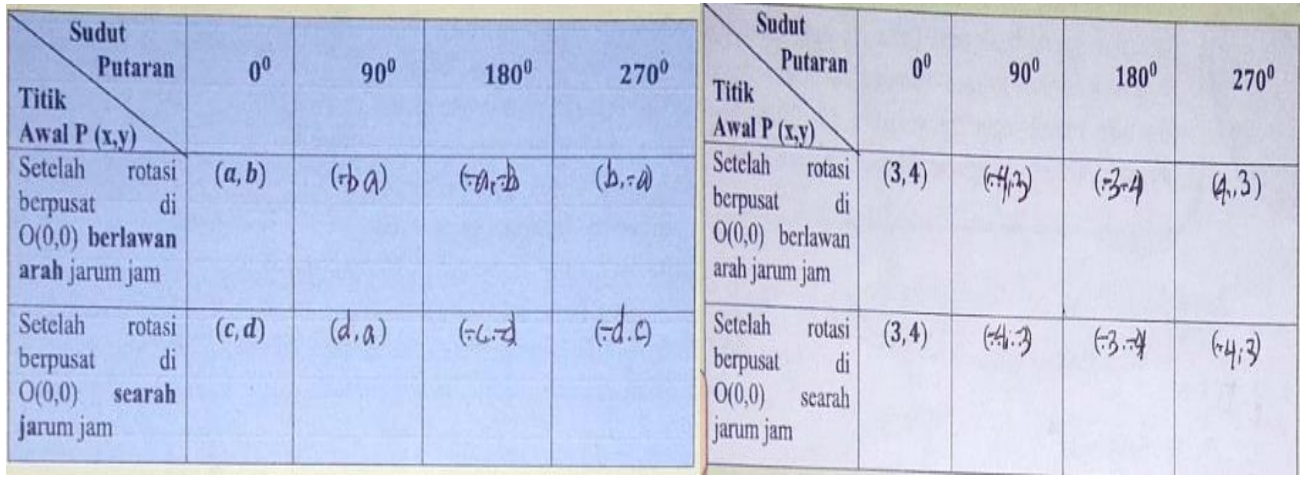

Gambar 8. Jawaban Peserta Didik Kemampuan Sedang.

Pada tahap akhir aktivitas 1 dilakukan oleh peserta didik adalah peserta didik diarahkan untuk menjawab masalah yang dikemukakan pada aktivitas satu dengan menyimpulkan model matematika yang diperoleh selama menggambar motif batik seragam sekolah Alya gunakan persamaan untuk rotasi titik di sekitar titik $\mathrm{O}(0,0)$ dengan sudut rotasi $90^{\circ}, 180^{\circ}$ dan $270^{\circ}$. Hasil 
pekerjaan peserta didik untuk menentukan rumus rotasi saat menggambar motif batik ditunjukkan pada Gambar di bawah ini Peserta didik kemampuan sedang masih ragu menentukan koordinat bayangan, sehingga masih terdapat kesalahan, Untuk mempertegas pemahaman peserta didik, peneliti mewawancarai peserta didik kemampuan sedang, karena dia membuat dengan bantuan gambar untuk menentukan koodinat bayangan, sebagai berikut.

Guru : Bagaimana cara kamu menentukan koordinat bayangan suatu titik?

PD-S : Saya membuat nya dengan cara membuat menggambar titik pada bidang koordinat

Guru : Ya benar, membuat hasil pemutaran bisa dengan membuat gambar. kira-kira apakah efektif membuat dengan gambar seperti ini?

PD- S : Iya Pak agak sedikit repot, apalagi jika titik koordinatnya, punya nilai yang cukup besar, bagaimana menggambarkan titik tersebut di bidang koordinat

Guru : Lalu bagaimana supaya lebih sederhana?

PD -S : Diperhatikan polanya Pak,

Guru : Coba dibuatkan nanti ya

Selanjutnya peserta didik memecahkan masalah lain yang umum dalam kehidupan sehari-hari, dalam hal ini permainan Bianglala, peserta didik menggunakan konsep dan rumus rotasi yang dipahami peserta didik.

Jadi dapat disimpulkan bahwa peserta didik kemampuan sedang dapat menentukan model matematis dalam proses menggambar motif batik seragam sekolah Alya tersebut dengan rumus rotasi suatu titik awal $\mathrm{O}(0,0)$ menghasilkan titik akhir setelah rotasi dengan besar sudut putaran $90^{\circ}, 180^{\circ}$ dan $270^{\circ}$ seperti Gambar 13 di atas, namun terdapat kekeliruan dalam menentukan hasil rotasi pada sudut putaran $270^{\circ}$. Sesuai dengan tingkat kesulitan yang dialami peserta didik karena kurang teliti atau masih ragu sehingga apa yang diprediksi bahwa peserta didik mengerti namun ada kesalahan dalam memperhatikan tanda pada sistim koordinat.

\section{Peserta Didik Berkemampuan Tinggi.}

Berdasarkan jawaban yang dibuat dalam LKPD Gambar 10:

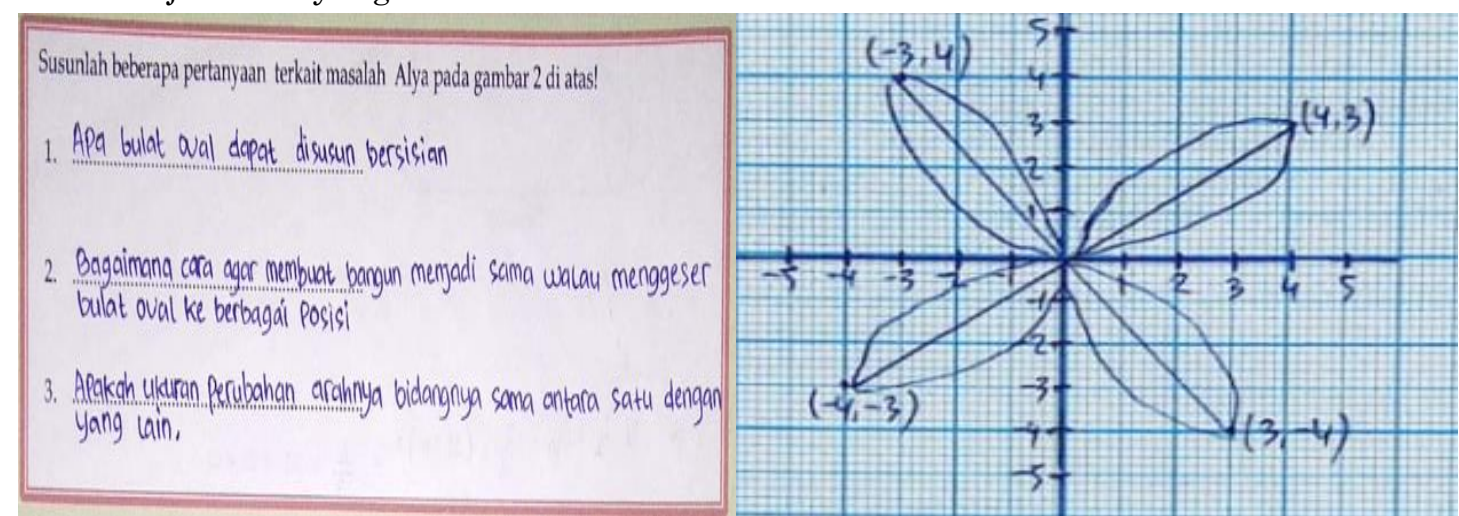

Gambar 9. Hasil Jawaban Peserta didik Kemampuan Tinggi

Peserta didik dengan kemampuan kemampuan tinggi sudah mengenal batik dan motif yang ditampilkan, tapi belum mengetahui hubungan motif batik dengan rotasi, Karena mereka menduga untuk membuat bentuk oval motif dengan menggeser sehingga dugaan mereka dapat disusun berisisan dengan menggeser. Namun mereka yakin dengan rotasi gambar motif batik dapat diteruskan. Selanjutnya dengan adanya percobaan yang dibuat pada Tabel yang ada di LKPD membuat peserta didik terinspirasi sehingga mereka mengenal dan mengetahui cara membuat bulatan oval seperti ellip. Dari LKPD yang telah dikerjakan oleh peserta didik kemampuan tinggi sudah mampu menyelesaikan masalah kontekstual yang diberikan sudah dapat mengaitkan gambar ellip yang mereka ketahui dengan membuat titik koordinat ujung ellip dan 
menuliskan titik titik pada setiap kuadran bahkan membuat masing- masing titik pada bidang koordinat

Apakah ada pola atau hubungan antara koordinat objek dan koordinat bayangan, Ketika titik A (a, b) diputar dengan sudut rotasi $90^{\circ}$ searah jarum jam dan $\mathrm{O}(0,0)$ adalah pusat rotasi, maka koordinat bayangan adalah A'(.., ...). Peserta didik berkemampuan tinggi. Berdasarkan jawaban yang dibuat dalam LKPD pada Gambar 11:

\begin{tabular}{|c|c|c|c|c|c|c|c|c|c|}
\hline $\begin{array}{l}\text { Sudut } \\
\text { Putaran } \\
\text { Titik } \\
\text { Awal P (x,y) }\end{array}$ & $0^{0}$ & $90^{\circ}$ & $180^{\circ}$ & $270^{\circ}$ & $\begin{array}{l}\text { Sudut } \\
\text { Titik } \\
\text { Awal } P(x, y)\end{array}$ & $0^{0}$ & $90^{\circ}$ & $180^{\circ}$ & $270^{\circ}$ \\
\hline $\begin{array}{l}\text { Setelah rotasi } \\
\text { berpusat di } \\
\mathrm{O}(0,0) \text { berlawan } \\
\text { arah jarum jam }\end{array}$ & $(a, b)$ & $\begin{array}{c}(\ldots, \ldots) \\
(-b, a)\end{array}$ & $\begin{array}{c}(\ldots, \ldots) \\
(-a,-b)\end{array}$ & $\begin{array}{c}(\ldots, \ldots) \\
(b,-a)\end{array}$ & $\begin{array}{l}\text { Setelah rotasi } \\
\text { berpusat di } \\
\mathrm{O}(0,0) \text { berlawan } \\
\text { arah jarum jam }\end{array}$ & $(3,4)$ & $\begin{array}{c}(\ldots, .) \\
(-4,3)\end{array}$ & $\begin{array}{c}(\ldots, \ldots) \\
(-3,-4)\end{array}$ & $\begin{array}{c}(\ldots, .) \\
(4,-3)\end{array}$ \\
\hline $\begin{array}{lr}\text { Setelah rotasi } \\
\text { berpusat } \quad \text { di } \\
O(0,0) \text { searah } \\
\text { jarum jam }\end{array}$ & $(c, d)$ & $\begin{array}{r}(\ldots, .) \\
(d,-c)\end{array}$ & $\begin{array}{r}(\ldots, . .) \\
(-c, d)\end{array}$ & $\begin{array}{c}(\ldots, . .) \\
(-b, c)\end{array}$ & $\begin{array}{lr}\text { Setelah } & \text { rotasi } \\
\text { berpusat } & \text { di } \\
O(0,0) & \text { searah } \\
\text { jarum jam } & \end{array}$ & $(3,4)$ & $\begin{array}{c}(\ldots, \ldots) \\
(4,-3)\end{array}$ & $\begin{array}{l}(\ldots, .) \\
(-3,-4)\end{array}$ & $\begin{array}{c}(\ldots, \ldots) \\
(-4,3)\end{array}$ \\
\hline
\end{tabular}

Gambar 10. Jawaban Peserta Didik Kemampuan Tinggi

Pada tahap akhir aktivitas 1 dilakukan oleh peserta didik, peserta didik diarahkan untuk menjawab masalah yang dikemukakan pada aktivitas satu dengan menyimpulkan bahwa model matematis yang diperoleh saat menggambar motif batik seragam sekolah Alya tersebut dengan rumus rotasi titik di sekitar titik $\mathrm{O}(0,0)$ dengan sudut rotasi sudut putaran $90^{\circ}, 180^{\circ}$ dan $270^{\circ}$. Peserta didik kemampuan tinggi sudah dapat menentukan koordinat bayangan, sehingga, lebih memahami apa pemutaran titik dengan memperhatikan arah jarum jam. Selanjutnya peserta didik memecahkan masalah lain yang umum dalam kehidupan sehari-hari, dalam hal ini permainan Bianglala, peserta didik menggunakan konsep dan rumus rotasi yang dipahami peserta didik. Jadi dapat disimpulkan bahwa peserta didik sangat berbakat dapat menentukan model matematis dalam proses menggambar motif batik seragam sekolah Alya tersebut dengan rumus rotasi suatu titik awal $\mathrm{O}(0,0)$ menghasilkan titik akhir setelah rotasi dengan besar sudut putaran $90^{\circ}, 180^{\circ}$ dan $270^{\circ}$.

\section{Aktifitas 2. Permainan Bianglala}

Tujuan Formal: Menentukan rumus hasil rotasi suatu titik awal $\mathbf{O}(0,0)$ dengan sudut putaran yang ditentukan

\section{Konteks 2}

Pernahkah Anda ke taman hiburan dan melihat permainan kincir ria seperti pada gambar di samping ini? Sebuah kincir ria selalu berputar pada porosnya. Game ini merupakan contoh penerapan konsep rotasi.

Gambar 11. Permainan Bianglala

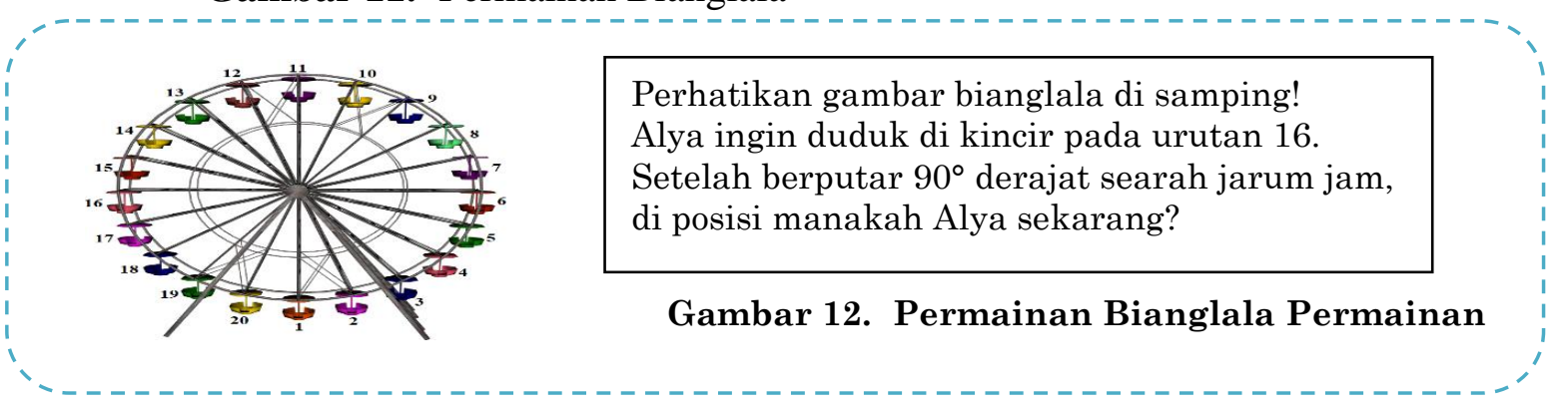

Peserta didik diharapkan dapat menjawab tentang persoalan tersebut. Berdasarkan LKPD yang dikerjakan peserta didik, sesuai kemampuannya adalah sebagai berikut: 


\section{Peserta Didik Berkemampuan Rendah.}

Berdasarkan jawaban yang dibuat dalam LKPD sebagai berikut:

Jawaban yang dikemukakan di atas ternyata pesrta didik sudah memahami rotasi dengan mengemukakan hal terkait dengan pemahaman konsep rotasi dan titik awal dan titik pusat rotasi, dan sudut rotasi. Hal ini menunjukkan bahwa dari aktifitas -aktifitas yang dilakukan dengan menyimpulkan beberapa percobaan, pesrta didik lebih paham. Hal ini juga terlihat pada jawaban peserta didik kemampuan rendah berikut ini.

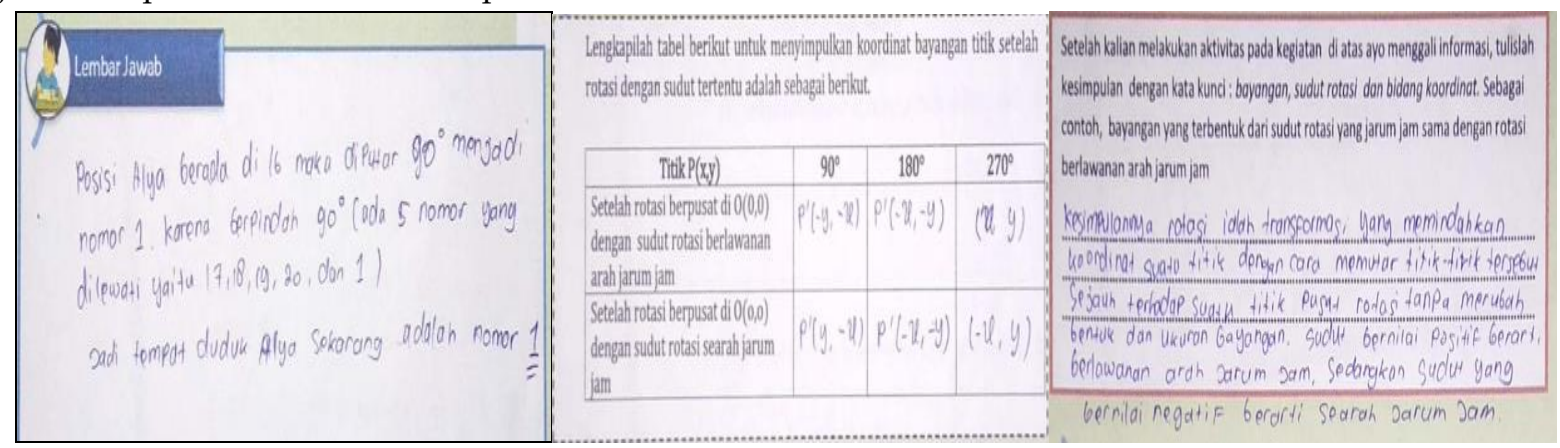

Gambar 13. Hasil Jawaban PD Kemampuan Rendah

Hasil wawancara kepada peserta didik kemampuan Rendah diberi pertanyaan, jawaban peserta didik tersebut ada yang membuat dalam kata-kata dan ada pula yang membuat langsung, dengan menebak saja. Namun pada jawaban tersebut, peserta didik sudah dapat menentukan jawaban, walaupun pada pertanyaan sebelumnya peserta didik menjawab salah.

Wawancara:

Guru : ananda, dari mana mendapatkan bayangannya?

PD- $\mathbf{R} \quad$ : saya tebak aja bapak.

Guru : ditebak aja? Padahal pertanyaan sebelumnya ananda tidak bisa jawab

PD- $\mathbf{R} \quad$ : iya Bapak, yang tadi memang tidak dapat.

Persoalan terakhir yang diberikan pada LKPD untuk Aktifitas 2 ini adalah penyelesaian masalah kehidupan sehari hari tentang permainan Bianglala yang menggunakan rotasi. Berdasarkan lembar jawaban peserta didik diperoleh hasil sebagai berikut: Jawaban peserta didik kemampuan Rendah salah, karena dia salah tafsir, dan juga diterka saja darimana datang 5 nomor untuk berpindah ( seharusnya berputar), dan konsep searah jarum jam tidak diperhatikan. Jika peserta didik mengetahui dari mana datang 5 nomor itu akan sangat membantu sehingga dilihat saja kemana arah rotasinya (dalam hal ini konteks searah jarum jam dimaksudkan peserta didik adalah setelah no 16). Selanjutnya dengan antisipasi guru membimbing peserta didik berkemampuan rendah untuk memami lagi dengan guru menukar titik awal dan berputar searah jarum jam. Memang peserta didik masih belum dapat membedakan arah positif dan negative. Bahkan peserta didik menduga arah positif adalah sudut yang searah dengan arah jarum jam Setelah diberikan arahan hingga pada tahap terakhir ini dilakukan sampai peserta didik memahami tentang konsep rumus rotasi.

\section{Peserta Didik Kemampuan Sedang}

Berdasarkan jawaban yang dikemukakan di atas ternyata pesrta didik sudah memahami rotasi dengan mengemukakan hal terkait dengan pemahaman konsep rotasi dan titik awal dan titik pusat rotasi, dan sudut rotasi. Hal ini menunjukkan bahwa dai aktifitas -aktifitas yang dilakukan dengan menyimpulkan beberapa percobaan, pesrta didik lebih paham. Hal ini juga terlihat pada jawaban peserta didik berikut ini. 

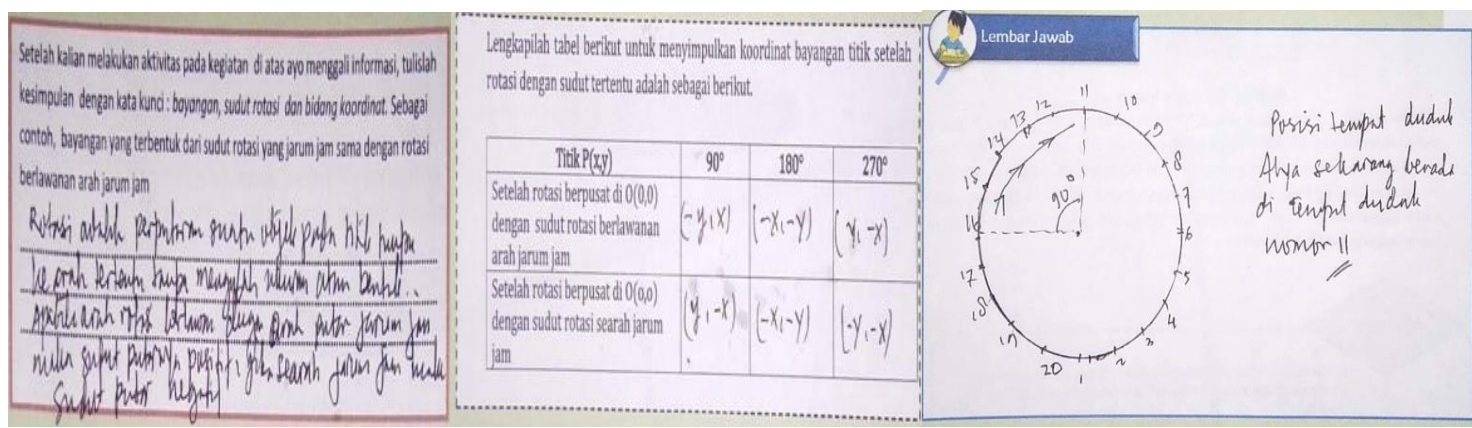

Gambar 14. Hasil Jawaban PD Kemampuan Sedang

Persoalan terakhir yang diberikan pada LKPD untuk Aktifitas 2 ini adalah penyelesaian masalah kehidupan sehari hari tentang permainan Bianglala yang menggunakan rotasi. Peserta didk kemampuan sedang ini guru membimbing dengan memecahkan masalah lain yang umum dalam kehidupan sehari-hari peserta didik menggunakan konsep dan rotasi yang dipahami peserta didik. Pada tahap akhir ini, peserta didik memahami konsep rumus rotasi, rumus rotasi, hal-hal yang mempengaruhi rotasi yaitu sudut rotasi dan arah rotasi, dan peserta didik menggunakan konsep dan rumus rotasi untuk menyelesaikan masalah. Kehidupan. Secara umum, aktivitas yang diberikan dalam mengerjakan LKPD tentang rotasi sesuai dengan prediksi, hanya saja peserta didk sering mengalami kesalahan karena kurang teliti dalam memperhatikan tanda pada negatif dan positif, karena setelah diwawancarai peserta didik paham arah putaran negatif dan positif.

\section{Peserta Didik Kemampuan Tinggi.}

Berdasarkan jawaban yang dibuat dalam LKPD sebagai berikut:

Berdasarkan jawaban yang dikemukakan di atas ternyata pesrta didik sudah memahami rotasi dengan mengemukakan hal terkait dengan pemahaman konsep rotasi dan titik awal dan titik pusat rotasi, dan sudut rotasi. Hal ini menunjukkan bahwa dari aktifitas -aktifitas yang dilakukan dengan menyimpulkan beberapa percobaan,pesrta didik lebih paham. Hal ini juga terlihat pada jawaban peserta didik kemampuan tinggi berikut ini.

\begin{tabular}{|c|c|}
\hline \multicolumn{2}{|c|}{ 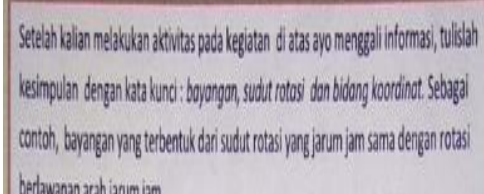 } \\
\hline Cotasi seafioh Jx & \\
\hline$-\left(0^{0}+\left(y_{1}-x\right)\right.$ & \\
\hline$-180^{\circ}+(-x, y)$ & 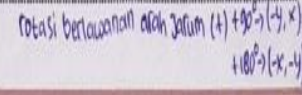 \\
\hline
\end{tabular}

\begin{tabular}{|c|c|c|c|}
\hline TitkP $P(x, y)$ & $90^{\circ}$ & $180^{\circ}$ & $270^{\circ}$ \\
\hline $\begin{array}{l}\text { Setelah rotasi berpusat di }(0,0) \\
\text { dengan sudut rotasi berlawalan } \\
\text { arahijanm jamm }\end{array}$ & $(-y, x)$ & $(-x,-4)$ & $(y,-x)$ \\
\hline $\begin{array}{l}\text { Setelah rotasiberpisatd } 0(0,0) \\
\text { dengan sudutr rotasis searah jarum } \\
\text { jamm }\end{array}$ & $(y,-x)$ & $(-x,-y)$ & $(-y, x)$ \\
\hline
\end{tabular}

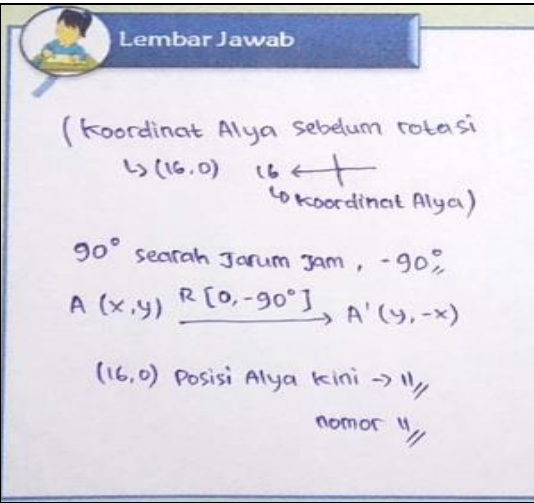

Gambar 15. Hasil Jawaban PD Kemampuan Tinggi

Hasil wawancara kepada peserta didik kemampuan tinggi diberi pertanyaan, menjawab dengan hasil yang benar pertanyaan yang diberikan. Namun jawaban yang dibuat tidak menggunakan konsep yang diberikan karena peserta didik tersebut membuatnya dengan cara lain seperti cara yang digukan di tingkat laanjut. Untuk itu ingin dilihat bagaimana jawaban kemampuan tinggi dari wawancara berikut:

Guru : ananda, cara apa yang ananda pakai pada jawaban tersebut?

PD- $\mathbf{T} \quad$ : dengan matriks Bapak? 
Guru : kenapa ananda sudah tau cara tersebut? Padahal belum diajarkan.

PD- T : saya telah mempelajari dan membahasnya pada private di Rumah saya Bapak

Guru : oh begitu. Terima kasih ya ananda. Semangat terus ya.

Peserta didik mampu menjawab dengan benar berdasarkan informasi yang telah dia dapatkan pada permasalahan sebelumnya. Persoalan terakhir yang diberikan pada LKPD untuk Aktifitas 2 ini adalah penyelesaian masalah kehidupan sehari hari tentang permainan Bianglala yang enggunakan rotasi. Pada tahap akhir ini peserta didik memahami konsep rumus rotasi, rumus rotasi dari arah positif dan negatif, faktor-faktor yang mempengaruhi rotasi yaitu sudut dan arah rotasi, dan peserta didik mampu memahami konsep dan rumus rotasi. digunakan untuk memecahkan masalah hari ini. Kehidupan. Pada umumnya semua kegiatan pembelajaran berlangsung secara bergantian, peserta didik memberikan jawaban interaktif dan menjelaskan alasan dari jawaban yang diberikan dan bahkan memberikan alternatif jawaban lain. Jadi capaian tujuan formal untuk aktifitas ini peserta didik dapat menuliskan bentuk formal dari rotasi suatu titik awal dan hasil rotasinya dengan benar.

\section{Pembahasan}

Desain HLT tidak dapat dipisahkan dari learning trajectory yang berisi rencana pelajaran dari mata pelajaran yang akan diajarkan. Dalam hal ini learning trajectory yang digunakan dalam kegiatan one to one ini adalah lebih memperdalam pemahaman istilah rotasi dalam konteks batik, kemudian pemahaman hubungan antara koordinat titik awal dan bayangan rotasi proses menggambar motif batik, setelah mencapai pemahaman ini penemuan rumus rotasi dengan pasti petunjuk dan langkah-langkah serta penerapannya untuk memecahkan masalah sehari-hari, di antaranya penggunaan rotasi dalam permainan Bianglala

Pada kegiatan one to one tiga peserta didik dipilih dengan ketentuan bahwa semua peserta didik yang dipilih adalah peserta didik yang sangat berbakat, cukup berbakat dan kurang berbakat. Peserta didik dengan kemampuan tinggi yaitu Rahma Alfin Khaira, kemampuan sedang Rianda Putra, kemampuan rendah yaitu Ribi Afnesia. Ada empat aktivitas yang dilakukan dalam one to one dan terbagi dalam fase yang berbeda, yaitu kegiatan dalam fase informal, metode, metode dan fase formal sebagai berikut.

\section{Pada Tahap Informal}

Aktifitas 1 yang dilakukan peserta didik menggambar motif batik salah satu pakaian seragam batik peserta didik SMP.yang dipakai di sekolah. Peserta didik diperkenalkan dalam LKPD nya tentang Batik sebagai warisan leluhur, dan pertanyaan yang diajukan tentang menggambar motif batik dengan memberikan pertanyaan kepada peserta didik tentang bagaimana masalah terdekat terkait dengan rotasi dan masalah terdekat terkait dengan rotasi dan menggambar motif batik) untuk menentukan hubungan antara titik dan titik pivo. Berdasarkan jawaban peserta didik dalam dari LKPD yang dikerjakan pada kegiatan one to one, diperoleh hasil kemampuan peserta didik: Setelah peserta didik selesai menggambar motif batik, ditemukan beberapa persepsi peserta didik yang berbeda-beda, seperti peserta didik dengan kemampuan rendah dan sedang maupun kemampuan tinggi sudah mengenal batik dan motif yang ditampilkan, tapi belum mengetahui hubungan motif batik dengan rotasi, Karena mereka menduga untuk membuat bentuk oval motif batik dengan menggeser sehingga dugaan mereka dapat disusun berisisan dengan menggeser. Namun dengan adanya antisipasi berupa percobaan dalam LKPD tersebut mereka pada akhirnya mulai mengenal dengan rotasi gambar motif batik dapat diteruskan peserta didik memahami bahwa desain batik dapat dibuat dengan memutar bentuk elips dengan arah dan sudut tertentu. 


\section{Tahap Model Of}

Kegiatan yang dilakukan pada tahap ini adalah peserta didik menggambar bentuk batik dengan menggunakan contoh bangun seperti bunga yang telah disediakan dan menggunakan kertas milimeter, Berdasarkan LKPD yang telah dikerjakan oleh peserta didik kemampuan rendah, peserta belum mampu menyelesaikan masalah kontekstual yang diberikan. Peserta didik tersebut hanya menggambar kembali gambar dengan menggabungkan semua bentuk ellip yang dibuat seperti rangkaian bunga. Hal ini berarti peserta didik masih belum mampu memanfaatkan prinsip rotasi. Peserta didik masih belum memahami konsep rotasi yang ada dalam motif batik Sedangkan peserta didik kemampuan sedang dan tinggi sudah dapat mengaitkan gambar ellip yang mereka ketahui dengan membuat titik koordinat ujung ellip dan menuliskan titik titik pada setiap kuadran.

Berdasarkan LKPD yang dibuat oleh peserta didik, peserta didik tampaknya tidak mengambil keputusan koordinat bayangan dengan benar. Peserta didik hanya langsung menerka saja jawaban. Namun pada kegiatan selanjutnya, peserta didik dapat memilih dengan membuat gambar pemutaran, walaupun masih terdapat kekeliruan dalam menentukan arah putarannya. Kemudian melalui wawancara dilakukan antisipasi dan membangkitkan rasa ingin tahu peserta didik dan peserta didik untuk mengetahui apa saja pola atau model matematika pada titik-titik rotasi yang diperoleh.

\section{Tahap Model For}

Berdasarkan LKPD yang dikerjakan peserta didik, kemampuan rendah dan sedang ternyata juga belum mampu memahami pola dari koordinat bayangan suatu bangun. Peserta didik sudah melakukan percobaan, namun hanya langsung menerka. dalam membuat koordinat bayangan dengan melihat pola, kemudian peserta didik mencari kemungkinan-kemungkinan jawaban-jawaban yang telah ditentukan dalam bentuk tabel. Berdasarkan LKPD yang dikerjakan peserta didik kemampuan tinggi, terlihat peserta didik mampu menentukan koordinat bayangan, akan tetapi peserta didik kurang tepat dalam memberikan keterangan pada arah putaran yang digunakan. Peserta didik telah membuat kemungkinan-kemungkinan jawaban. Dari hasil percobaan peserta didik kemudian mengganti nilai-nilai x dan y dengan simbol titik dengan angka yang ditentukan. Hal ini dilakukan dengan tujuan untuk memudahkan peserta didik dalam memahami hubungan antara koordinat awal dan koordinat bayagan hasil rotasi, sehingga nanti dia dapat memodelkannya.

\section{Tahap Formal}

Peserta didik kemampuan rendah dan sedang menggunakan gambar atau memperhatikan bantuan yang telah disediakan dalam percobaan, koordinat hasil rotasi seperti yang sudah mereka kerjakan. Setelah itu, mereka gunakan pola suatu model matematis dari hubungan dan gunakan model untuk memutar titik tertentu. Peserta didik kemampuan tinggi dapat menggunakan model matematika yaitu menggunakan model matriks, padahal belum diajarkan oleh guru matematikanya. Dari hasil wawancara ternyata peserta didik telah mempelajari dan membahasnya pada private les di rumah. Dalam hal ini peserta didik dengan kemampuan tinggi mampu menjawab dengan benar berdasarkan informasi yang telah dia dapatkan pada permasalahan sebelumnya.

Setelah aktivitas satu dilakukan oleh peserta didik, beberapa peserta didik memprediksi bahwa masalah yang dikemukakan pada aktivitas satu adalah masalah yang tidak begitu sulit dengan alasan bahwa peserta didik dapat menjawab pertanyaan tersebut ada yang membuat dalam kata-kata dan ada pula yang membuat langsung dengan koordinat bayangan Dengan prediksi ini, di akhir kegiatan, ternyata peserta didik mampu menentukan koordinat bayangan sesuai dengan masalah kontekstual yang diberikan. Peserta didik telah mampu menerapkan konsep 
rotasi dan menyelesaikan masalah berdasarkan pengetahuan yang telah ia dapatkan pada materiyang telah dipelajari pada saat kelas VII. Dalam hal ini peserta didik dapat menguji prediksi mereka di awal. Hal ini akan membuat peserta didik bersemangat atau termotivasi dalam mengerjakan masalah yang ada pada aktivitas selanjutnya.

Aktivitas dua, bertujuan agar peserta didik menerapkan hasil pemutaran suatu objek. Dalam mengerjakan aktivitas ke dua ini umumnya semua peserta didik dapat mengerjakannya membuat koordinat titik bayangan dengan membuat gambar dan pola. Peserta didik mengalami kesulitan pada saat membuat gambar. Karena dianggap tidak efektif maka peserta didik tersebut memperhatikan pola koordinat dari bayangan suatu objek. Berdasarkan jawaban pada LKPD peserta didik tersebut terlihat bahwa telah mampu menentukan koordinat bayangan suatu objek dengan menggunakan gambar dan dalam hal ini, siswa telah membuat pola dari koordinat bayangan yang lebih mudah dan simpel, walaupun masih ada membuat keterangan yang kurang tepat pada setiap arah putarannya.

Berdasarkan jawaban dan wawancara peserta didik, bahwa peseerta didik tersebut menentukan koordinat bayangan suatu objek dengan membuat gambar. Lalu pada keterangan koordinat bayangan tersebut, peserta didik membuat keterangan pada arah jarum jam padahal seharusnya itu menunjukkan "arah negatifr dan arah positif". Maka dari itu tugas guru dalam hal ini adalah memberi pertanyaan-pertanyaan stimulus untuk merangsang peserta didik agar tidak salah dalam mengartikan atau membuat keterangan untuk sudut putaran. Berdasarkan kedua aktivitas ini apa yang siswa lakukan dengan LKPD ini, siswa dapat menemukan sendiri koordinat bayangan suatu objek dengan sudut putaran yang ditentukan. Apa yang diprediksi dan diharapkan dapat diimplementasikan dalam desain LKPD,

\section{Kesimpulan}

Dihasilkan hypothetical learning trajectory pada topik transformasi geometri tentang Rotasi. Pada penerapan one to one, di kelas IX.1 SMPN 7 Bukittinggi Siswa dengan keterampilan sedang dan tinggi dapat merespons seperti yang diprediksi pada HLT, tetapi antisipasi siswa yang berkemampuan rendah saat melakukan wawancara agar siswa dapat menjawab pertanyaan yang diajukan. Pada penerapan apa yang diprediksi dan antipasi yang dilakukan pada desain HLT tentang topik transformasi geometri tentang Rotasi sesuai hasil yang dirancang dengan pelaksanaan proses pembelajaran di sekolah. Terbukti dalam proses wawancara dengan guru dan peserta didik dapat menggunakan desain yang dikembangkan karena memiliki urutan pengajaran yang sistematis untuk mengajar mata pelajaran transformasi geometri tentang Rotasi

\section{Daftar Pustaka}

[1] Alim, J. A., Hermita, N., Sari, I. K., Alpusari, M., Sulastio, A., Mulyani, E. A., Putra, R. A., \& Arnawa, I. M. (2020). Development of Learning Flow for KPK Based on Interactive Multimedia Assisted RME Based on Students PGSD UNRI. Journal of Physics: Conference Series, 1655, 012045. https://doi.org/10.1088/1742-6596/1655/1/012045.

[2] Andrews-Larson, C., Wawro, M., \& Zandieh, M. (2017). A hypothetical learning trajectory for conceptualizing matrices as linear transformations. International Journal of Mathematical Education in Science and Technology, 48(6), 809-829. doi: 10.1080/0020739X. 2016.1276225 .

[3] Ayunika, Elisabet. (2011). Pengembangan Hipotesis Trayektori Pembelajaran UntukKonsep Pecahan. Yogyakarta: PendidikanMatematika Universitas Sanata Dharma. 
[4] Bluman, A. G. (2012). Elementary statistics: A step by step approach. 8th ed. New York: McGraw Hill.

[5] Bohamonde, D.C, Joan, J.M.F. \& Aymemi. (2017). Mathematical modelling and the learning trajectory: tools to support the teaching of linear algebra. International Journal of Mathematical Education in Science and Tchnology, 48(3). doi:10.1080/0020739X.2016.1241436

[6] Camci, F., \& Tanışl, D. (2020). Sixth-Grade Students' Mathematical Abstraction Processes in a Teaching Experiment Designed Based on Hypothetical Learning Trajectory. TED EĞİTIM VE BILIM. https://doi.org/ 10.15390/eb.2020.8464.

[7] Dawkins, P. C. (2015). Explication as a lens for the formalization of mathematical theory through guided reinvention. The Journal of Mathematical Behavior, Volume 37: 63-82. https://doi.org/10.1016/j.jmathb.2014.11.002.

[8] Fauzan, A., \& Diana, F. (2020). Learning trajectory for teaching number patterns using RME approach in junior high schools. Journal of Physics: Conference Series, 1470(1). https://doi.org/10.1088/1742-6596/1470/ 1/012019.

[9] Ekawati, R., Wintarti, A., Abadi, \& Kurniasari, I. (2020). Integrating the Hypothetical Learning Trajectory with Realistic Mathematics to In-Service Teachers' Professional Development. International Conference on Research and Academic Community Services (ICRACOS 2019). https://doi.org/10.2991/icracos-19.2020.36.

[10] Faizal Amir, M., Fediyanto, N., Chotimah, C., \& Rudiyanto, H. E. (2018). Developing 3Dmetric media prototype through a hypothetical learning trajector to train students spatial skill. Journal of Advanced Research in Dynamical and Control Systems, 10(2 Special Issue). https://doi.org/10.31227/osf.io/vmk45.

[11] Febrian, F., \& Astuti, P. (2018). The RME principles on geometry learning with focus of transformation reasoning through exploration on Malay woven motif. Journal of Turkish Science Education, 15(Special Issue). https://doi.org/10.12973/tused.10254a

[12] Fuadiah, N. F., \& Sawitri, Z. A. (2020). A new learning trajectory on the pyramid volume for secondary school. Journal of Physics: Conference Series, 1480(1). https://doi.org/10.1088/1742-6596/1480/1/012028

[13] Gee, E., Fauzan, A., \& Atmazaki, A. (2018). Designing learning trajectory for teaching sequence and series using RME approach to improve students' problem solving abilities. The 6th South East Asia Design Research International Conference (6th SEA-DR IC), 1088, 1-6. https://doi.org/10.1088/1742-6596/1088/1/ 012096

[14] Gravemeijer, K. (2014). Design research on local instruction theories in mathematics education. Development of Mathematics teaching: Design, Scale, Effects. Proceedings of Madif 9 (The Ninth Swedish Mathematics Education Research Seminar Umeå).

[15] Huang, R., Zhang, Q., Chang, Y. ping, \& Kimmins, D. (2019). Developing students' ability to solve word problems through learning trajectory-based and variation task-informed instruction. ZDM - Mathematics Education, 51(1). https://doi.org/10.1007/s11858-018-0983-8

[16] Jacob, B. L. (2013). The Development of Introductory Statistics Students' Informal Inferential Reasoning and Its Relationship to Formal Inferential Reasoning. Teaching and Leadership - Dissertations. 245. https://surface.syr.edu/tl_etd/245

[17] Larsen, S. P. (2013). A local instructional theory for the guided reinvention of the group and isomorphism concepts. The Journal of Mathematical Behavior, 32(4), 712-725. https://doi.org/10.1016/j.jmathb.2013.04.006

[18] Lemsan, S. C., \& House, L. (2012). mproving Mr. Miyagi's Coaching Style: Teaching Data Analytics with Interactive Data Visualizations, CHANCE, 25:2, 4-12. http://dx.doi.org/10.1080/09332480.2012.685362.

[19] Morris, T. \& Paulsen, R. 2011. Using Tracing Paper to Teach Transformation Geometry. Jurnal Amesa. ISBN 978-0-620-47379-8. Johannensberg: Amesa, pp 129. 
[20] Maulani, F. I., \& Zanthy, L. S. (2020). Analisis kesulitan siswa dalam menyelesaikan soal materi transformasi geometri. Jurnal Gammath, 5, 16-25.

[21] Mukasyaf, F., Fauzi, K. M. A., \& Mukhtar, M. (2019). Building Learning Trajectory Mathematical Problem.

[22] Nickerson, S. D., \& Whitacre, I. (2010). A local instruction theory for the development of number sense. Mathematical Thinking and Learning, 12(3), 227-252. https://doi.org/10.1080/10986061003689618.

[23] Solving Ability in Circle Tangent Topic by Applying Metacognition Approach. International Education Studies, 12(2). https://doi.org/10.5539/ies.v12n2p109.

[24] Özdemir, B. G. (2017). Mathematical Practices in a Learning Environment Designed By Realistic Mathematics Education: Teaching Experiment About Cone and Pyramid. European Journal of Education Studies, 3(5).

[25] Rollick, M. B. 2009. Toward a Deffinition of Reflection. Jurnal Mathematics Teaching in the Middle School. Vol 7, pp 397.

[26] Safitri Devy, Halini, \& Nursangaji, A. (2020). Analisis Kesalahan Siswa dalam Menyelesaikan Persamaan Kuadrat di Kelas XI SMAN 5 PONTIANAK. Jurnal Pedidikan Dan Pembelajaran Khatulistiwa, 7(8), 1-6.

[27] Sari, A., \& Julianti, B. (2018). Asessing Hyphotetical Learning Trajectory of Mathematics Teachers. Journal Of Teaching And Learning In Elementary Education (JTLEE), 1(1). https://doi.org/10.33578/jtlee.v1i1.5388.

[28] Sembiring, R., S. Hadi and M. Dolk, 2008. Reforming mathematics learning in Indonesian classrooms through RME. ZDM - International Journal on Mathematics Education, 40(6): 927-939.Available at: https://doi.org/10. 1007/s11858-008-0129.

[29] Atikah Sari. (2007). Masalah Kontekstual Sebagai Batu Sendi Matematika Sekolah. Surabaya: Pusat Sains Dan Matematika Sekolah UNESA.

[30] Suryadi, D. (2013). Didactical Design Research (Ddr) Dalam Pengembangan Pembelajaran Matematika. Prosiding Seminar Nasional Matematika Dan Pendidikan Matematika STKIP Siliwangi Bandung, 1(2).

[31] Taufina, T., Chandra, C., Fauzan, A., \& Ilham Syarif, M. (2019). Development of Statistics in Elementary School Based RME Approach with Problem Solving for Revolution Industry 4.0. 5th International Conference on Education and Technology (ICET 2019), 716-721. https://doi.org/10.2991/icet-19.2019.172.

[32] Towe, M. M., \& Julie, H. (2020). Developing learning trajectories with the RME of phytagorean theorem. Journal of Physics: Conference Series, 1470(1). https://doi.org/10.1088/1742$6596 / 1470 / 1 / 012027$.

[33] Van den Heuvel-Panhuizen, M., \& Drijvers, P. (2020). Realistic mathematics education. S. Lerman (ed.), Encyclopedia of Mathematics Education. DOI 10.1007/978-94-007-4978-8,

[34] Yuliani, R. E., Suryadi, D., \& Dahlan, J. A. (2018). Hypotetical learning trajectory to anticipate mathematics anxiety in algebra learning based on the perspective of didactical situation theory. Journal of Physics: Conference Series, 1013(1). https://doi.org/10.1088/1742$6596 / 1013 / 1 / 012137$.

[35] Zulkardi, 2010. How toDesign Mathematics Lessons based on the Realistic Approach?. www.reocities.com/ ratu ilma/rme.html. 